\title{
ГОСУДАРСТВЕННАЯ СЛУЖБА В ОРГАНАХ ВНУТРЕННИХ ДЕЛ КЫРГЫЗСКОЙ РЕСПУБЛИКИ
}

\begin{abstract}
Аннотация: Предметом исследования является правовые и организационные проблемы формирования и реализации законодательства о государственной службе в органах внутренних дел Кыргызской Республики. Объектом исследования является комплекс общественных отношений, которые урегулированы нормами административного права, которые складываются в срере внутренних дел. Автор подробно рассматривает базовые элементы института государственной службы функционирующего в органах внутренних дел данной республики, особо обращает внимание на проблему противодействия коррупции. Также обращается внимание на проблему работы с кадрами ОВД, на проблему исключения протекционизма в системе государственной службы в органах внутренних дел. Методологическую основу статьи составили современные достижения теории познания. В процессе исследования применялись общесрилософский, теоретический методы (диалектика, системный метод, анализ, синтез, аналогия, дедукция, наблюдение, моделирование), традиционно правовые методы, методы, используемые в конкретно-социологических исследованиях. Основные выводы проведенного исследования состоят в том, что правовые основы государственной службы в органах внутренних дел Кыргызской Республики тесно переплетаются с аналогичными правовыми основами, которые сформировались в Российской Федерации относительно данного вида государственной службы. Вкладом автора является то, что он впервые рассматривает институт данного вида государственной службы в нашей стране. Новизна исследования определяется целым рядом обстоятельств, в частности обусловленных использованием метода сравнительного правоведения. Статья может являться базой для более углубленного изучения государственной службы 8 государствах участника СНГ.
\end{abstract}

Ключевые слова: служба, Киргизия, полиция, управление, сотрудник, чиновник, МВД, срера, коррупция, регулирование.

$\mathrm{P}$ оссийская государственная служба давно является объектомвсестороннего изучения представителями российской науки различныхгуманитарных направлений и, прежде всего, юристов. Напротив, государственная служба других государства, возникших на постсоветском пространстве, практически не привлекает их внимания. Известны лишь единичные публикации юридического профиля, посвященные указанной тематике [1]. Получить достаточно полную и достоверную информацию о государственной службе данных стран обычно удается только из немногочисленных докторских и кандидатских диссертаций, которые защищаются в Россииавторами из бывших союзных республик [2]. Между тем, постсоветское пространство и, особенно, страны-члены Содружества Независимых Государств, является одним из безусловных приоритетов внешней политики Российской Федерации. Его значимость объективно возрастает в связи с образованием Таможенного Союза, углублением интеграционнных процессов, которые происходят на постсоветском пространстве.Нельзя такжене отметить, что в пост- советских государствах, пожалуй, за исключением вступивших в Европейский Союз стран Балтии, а также отчасти Грузии, государство продолжает доминировать в экономике,сохраняя определяющее влияние на все сферы общественной жизни. При таком положении, очевидно,исключительно велики роль и значение государственного аппарата и корпуса государственных служащих, составляющего его основу.

Кыргызская Республика - одно из государств, возникших после распада СССР. Несмотря на более чем два десятилетия, прошедшие после обретения независимости, можно констатировать, что отдельные государственные институты в Кыргызской Республике только формируютсяи процесс этот далек от завершения. В результате, констатируетсяв Национальной стратегии устойчивого развития Кыргызской Республики на период 2013-2017 годы, утвержденной Указом Президента Кыргызской Республики от 21 января 2013 г. № 11 [3], многие международные эксперты и наблюдатели по-прежнему относят Кыргызстан в разряд «недееспособных» государств. Подверга- 
ют сомнению перспективы самой кыргызской государственности.

При таком положении укрепление и развитие государственной службы становится насущной необходимостью, залогом сохранения Кыргызской Республики как суверенного независимого государства.Поэтому, институту государственной службы, неотъемлемой составляющей которого является государственная служба в органах внутренних дел,политическое руководство страны уделяет пристальное внимание. Делается это еще и потому, что для постсоветских государств и Кыргызская Республика в данном случае исключением не является национальная государственная служба - один из важных атрибутов государственности, подчеркивающих их суверенитет. Значимой особенностью следует признать и то, что государственная служба в Кыргызской Республике развивается при деятельной поддержке международных организаций, в частности, Управления Организации Объединенных Нацийпо наркотикам и преступности (УНП ООН) с ориентациейна опыт правового регулирования и организации государственнойслужбы правовых экономически развитых государств современного мира. Такое положение в определенной мере подтверждает справедливость высказывавшегося в специальной литературе мнения о том, чтоКиргизия - страна, которая на протяжении постсоветского времени решает проблемы строительства своей государственности в основном за счет внешних доноров [4].

Однако даже международная помощь пока не обеспечила серьезных улучшений в деятельности органов внутренних дел. В упомянутой выше Национальной стратегии устойчивого развития Кыргызской Республики на период 2013-2017 годы годыконстатировалось, что сложившаяся за годы независимости система правопорядка, организации и деятельности органов внутренних дел, их структура не соответствуют новым политическим и экономическим условиям функционирования государства и общества, закрепленным в действующей Конституции Кыргызской Республики. Именно поэтому продолжается работа по совершенствованию деятельности органов внутренних дел, включая государственную службу их сотрудников.

Нормативная правовая база. Правовые основы государственной службы Кыргызской Республики заложены в ее Конституции, принятой референдумом (всенародным голосованием) 27 июня 2010 г [5]. При этом, нельзя не отметить, что конституционный строй Кыргызской Республики заметно отличается от российского, что не могло не сказаться и на организации государственной службы в органах внутренних дел. Основные полномочия в сфере ее регулирования сосредоточены в Правительстве Кыргызской Республики, тогда как в Российской Федерации - это прерогатива Главы государства.

Что касается конституционных норм, то важнейшее значение имеет закрепленное в ч. 4 ст. 51 положение о том, что граждане имеют равные права, равные возможности при поступлении на государственную и муниципальную службу, продвижение в должности в порядке, предусмотренном законом. Данное общее право в полной мере распространяется и на государственную службу в органах внутренних дел, которая является самостоятельной разновидностью государственной службы. В данном случае хорошо видно, что норма кыргызстанскойКонституции заметно шире, чем схожая по содержанию норма ч. 4 ст. 32 Конституции Российской Федерации, закрепляющая право гражданина на равный доступ к государственной службе.

Кроме того, на конституционный уровень выведен запрет для сотрудников правоохранительных органов и военнослужащих на членство в политических партиях (п. 2 ст. 4).Очевидно, что данный запрет распространяется и на сотрудников органов внутренних дел.

Также в ч. 4 ст. 5 Конституции Кыргызской Республики закреплена общая норма, в полной мере относящаяся и к органам внутренних дел, о том, что государственные органы и их должностные лица несут ответственность за противоправные действия в порядке, предусмотренном законом.

Для большинства государств современного мира традиционно положение, когда в нормах конституции определяются лишь самые общие положения, касающиеся того или иного института. Они требуют конкретизации, которая, как правило, осуществляется уже в текущем законодательстве, законах и подзаконных нормативных правовых актах. Республика Кыргызстан в этом отношении не исключение. Конституционные нормы получили дальнейшее развитие и детализацию в специальном законодательстве Кыргызской Республики.

Действительно, наряду с Конституцией правовую основу государственной службы Кыргызской Республики составляют принятые на ее базе иные нормативные правовые акты. Прежде всего это Закон Кыргызской Республики от 11 января 1994 года № 1360-XII «Об органах внутренних дел Кыр- 
гызской Республики» [6]. (далее - Закон). Кроме того, на основании ст. 7 данного законапорядок и условия прохождения службы рядовым и начальствующим составом органов внутренних дел также регламентируются Положением, утверждаемым правительством Кыргызской Республики. В настоящее время действует Положение, утвержденное постановлением Правительства Кыргызской Республики от 20 июля 2013 года № 360 [7]. (далее - Положение). Нельзя не отметить, что до принятия ныне действующей Конституции Кыргызской Республики 2010 года Положение о прохождении службы рядовым и начальствующим составом органов внутренних дел Кыргызской Республики было утверждено Указом Президента Кыргызской Республики от 30 октября 2009 года УП № 480 [8]. Однако в связи с принятием Конституции Кыргызской Республики 2010 года произошло перераспределение полномочий между президентом страны и ее правительством. В настоящее время, как уже отмечалось вышеправительство, а не Президент Кыргызской Республики обладает основными полномочиями в сфере внутренних дел. Именно оно утверждает структуру органов внутренних дел и Положение о Министерстве внутренних дел. Министр внутренних дел Кыргызской Республики подчиняется Премьер-Министру и несет персональную ответственность за свою деятельность перед Правительством Кыргызской Республики (ч. 1 ст. 1 Закона).

На тех, кто служит в органах внутренних дел, как лиц, имеющих статус сотрудников правоохранительных органов, также распространяется действие Закона Кыргызской Республики от 11 августа 2004 года № 114 «0 государственной службе» [9], но только в той мере, в какой их профессиональная деятельность не урегулирована специальными законами(ст. 3 данного Закона). Таким образом, хотя служба в органах внутренних дел, как разновидность милитаризованной государственной службы, по своему характеру и содержанию явно тяготеет к военной службе, можно говорить, что она в определенной мере связана и с государственной службой в гражданской части государственного аппарата.

В литературе, посвященной службе в органах внутренних дел Кыргызской Республики, высказывалось мнение о том, что действующее законодательство в данной области не полностью отвечает всевозрастающим требованиям, предъявляемым к сотрудникам органов внутренних дел, а также их организационно-защитным механиз- мам. По мнению кыргызстанского ученого-юриста 3.А.Мамырбаевой, одной из причин этого является отсутствие закона о государственной службе в органах внутренних дел [10]. Не отрицая значимости именно законодательного регулирования, следует все же сказать, что сам по себе закон - это не панацея от существующих проблем в сфере государственной службы в органах внутренних дел. Главное - необходимо обеспечить безусловное исполнение положений действующего законодательства о государственной службе в органах внутренних дел хотя бы они и были установлены подзаконным актом, каковым, к примеру, является постановление Правительства Российской Федерации от 20 июля 2013 г. № 360.

Давая общую характеристику службы в органах внутренних дел, следует сказать, что согласно п. 9 Положения эта служба дел является государственной службой граждан Кыргызской Республики. При этом она отличается особыми условиями, повышенной ответственностью за характер и результаты действий, связана с постоянным риском для жизни и здоровья, характеризуется эмоциональной насыщенностью и требует физической выносливости.

По мнению автора, для службы в органах внутренних дел, впрочем как и для всего государственного аппарата Кыргызской Республики, характерно наличие двух тесно связанныхжду собой негативных факторов, умолчать о которых нельзя. Это - родоплеменные связи и коррупция.

Родоплеменные связи. Огромное влияние родоплеменные связи традиционного кыргызского общества оказывают на органы государственного управления. Независимо от полученного образования и круга общения любой киргиз, прежде всего, относит себя к определенному роду [11]. Каждый государственный служащий в Кыргызстане всегда пытается сохранить связи со своим родом. Больше всего это проявляется в высших эшелонах власти, где практически вся система управления строится на принципах непотизма и привлечения «своих» - родственников и земляков, которые всегда поддержат в случае необходимости. Так формируются неформальные союзы, члены которых крепко связаны друг с другом и взаимно заинтересованы в продвижении своего главного представителя [11.1.]. В результате широкое распространение в Кыргызстане получил так называемый трайболизм [12]. Данное явление не могло не отразиться и на государственной службе, включая службу в органах внутренних дел. Справедливости ради 
нужно сказать, что киргизстанские ученые-юристы, исследующие государственную службу своей республики, не замалчивают наличие данного явления, которое рассматривается ими как один из основных негативныхфакторов в государственном аппарате.Так, Н.Т.Шерипов, выделяет трайболизм в качестве одного из негативных явлений в сфере государственной службы Кыргызстана испециально отмечает, что оно наряду с другими проблемами способно привести к значительному ухудшению кадрового состава, что неизбежно отразится на эффективности деятельности госорганов и в целом государства. При этом в качестве средства преодоления данного явления справедливо предлагается реализация комплексного подхода при конкурсном отборе кандидатов на государственные должности [13].

Законодательство Кыргызской Республики предусматривает, что замещение отдельных вакантных должностей младшего, среднего и старшего начальствующего состава в системе органов внутренних дел осуществляется на конкурсной основе(п. 21 Положения). При этом порядок проведения конкурса и перечень должностей, замещение которых осуществляется на конкурсной основе, определяется Правительством Кыргызской Республики. Здесь хотелось бы заметить, что конкурсы только тогда дадут ожмдаемый результат, когда должности, на которые он объявляются будут привлекательны для потенциальных кандидатов, причем кандидатов достойных, обладающих профессиональными и личными качествами. В противном случае конкурс будет формальностью. Да, его будут объявлять и проводить, но отобрать качественные кадры он не позволит. Если обратиться в опыту нашей страны, то,как верно отмечает современный российский исследовательН.И.Разуваева, только в ходе системного реформирования государственной службы и реформы системы МВД России возникли правовые, организационные и, что немаловажно, экономические условия (значительно возросло денежное содержание сотрудников) для замещения должностей в органах внутренних дел по конкурсу [14]. Справедливость подобной оценки подтверждается и главой МВД России В.А.Колокольцевым, который, выступая на расширенном заседании коллегии МВД России с участием Президента Российской Федерации, подчеркнул, что повышение престижа полицейской профессии позволило перейти на конкурсную основу комплектования подразделений [15]. Думается, что для внедрения конкурсных начал при замещении должностей в органах внутренних дел Кыргызской Республики еще предстоит проделать большую и трудную работу. Учитывая сложное социально-экономическое положение в стране в сочетании с отмеченными выше национальными особенностями, в обозримой перспективе ожидать этого вряд ли приходится. Тем не менее, есть основания полагать, что в ходе реформирования органов внутренних дел Кыргызской Республики будет предпринята попытка шире применять открытый конкурсный набор на должности в органах внутренних дел. Это признается одним из основных направлений реализации мер по реформированию органов внутренних дел, утвержденных Постановлением Правительства Кыргызской Республики от 30 апреля 2013 года № 220. Однако, повторимся, для успеха намеченных мероприятий нужны соответствующие условия.

В законодательстве учитываются национальные особенности и традиции современного кыргызстанского общества. Так, согласно п. 106 Положения сотрудник увольняется со службы в запас (с постановкой на воинский учет), в частности, при осуждении его близких родственников за особо тяжкие преступления. С данной норме корреспондируется подпункт «в» п. 32 Положения, согласно которому гражданин не может быть принят на службу в органы внутренних дел, если его близкие родственники (родители, супруг (a), братья, сестры и дети) осуждены за умышленные особо тяжкие преступления.

Кроме того, в качестве одного из сквозных приоритетов реформы органов внутренних дел в соответствии с Национальной стратегией устойчивого развития Кыргызской Республики на период 2013-2014 годы называется, в частности, формирование многонационального кадрового состава органов внутренних дел. Тем самым сделан важный шаг на пути создания состава, который отражал бы интересы не только численно доминирующей так называемой «титульной нации» каковой являются киргизы, но был бы своеобразным «срезом» общества современного Кыргызстана. Обеспечение данного приоритета видится во введении в органах внутренних дел гарантированных квот должностей, прежде всего, должностей старшего и высшего начальствующего состава для представителей других значительных по численности народов, населяющих республику (казахи, русские, узбеки).

Коррупция .Исключительно остро для Кыргызской Республики стоит проблема коррупции, тесно связанная с проблемой родоплемен- 
ных связей. Данная проблема характерна для большинства государств постсоветского пространства, не исключая, к сожалению, и Россию. По данным авторитетной международной организации TransparencyInternational, осуществляющей мониторинг Конвенции ООН против коррупции от 31 октября 2003 года, в 2014 году Кыргызстан имел индекс восприятия коррупции (TheCorruptionPerceptionsIndex) 27 баллов по 100-бальной шкале (136 место из 174 государств современного мира) [16]. Данный показатель в 2013 и 2012 годах составлял соответственно 24 балла (154 место из 177) и 24 балла (164 место из 182 государств). Как видно, имеет место пусть и минимальная, но все же некоторая положительная динамика. Несмотря на это, следует признать, что проблема коррупции не только сохраняется, но и усугубляетсяименно из-затехродоплеменных связей, которые устойчиво присутствую в современном кыргызстанском обществе. Думается, глубоко прав К.С.Бельский, который отмечает, что высокий уровень коррупции в государстве, как правило, свидетельствует о слабости системы государственного управления и о моральной запущенности значительной части общества [17]. Убедительным подтверждением слов ученого является существующая ныне коррупционная ситуация в Кыргызстане. Правда, следует оговориться, что его слова в полной мере относятся к, если так можно выразиться, обществу, основанному на европейской культуре и христианских ценностях, и в меньшей степени применимы к восточному обществу, где во многом иные традиции и ценностные ориентиры.

Основным правовым средством преодоления коррупции является Закон Кыргызской Республики от 8 августа 2012 г. № 153 «0 противодействии коррупции» [18]. В ст. 1 данного нормативного правового акта коррупция определяется как умышленные деяния, состоящие в создании противоправной устойчивой связи одного или нескольких должностных лиц, обладающих властными полномочиями, с отдельными лицами или группировками в целях незаконного получения материальных, любых иных благ и преимуществ, а также предоставление ими этих благ и преимуществ физическим и юридическим лицам, создающие угрозу интересам общества или государства.

Нельзя не отметить, что в Законе Кыргызской Республики от 8 августа 2012 г. № 153 «0 противодействии коррупции» широко используется понятие «коррупционное правонарушение». Однако, так же как и в отечественном Федеральном законе от 27 июля 2004 г. «0 государственной гражданской службе Российской Федерации» оно, к сожалению, не раскрывается, что вряд ли правильно. Думается, в ходе совершенствования антикоррупционного законодательства следовало бы закрепить де-юре соответствующую дефиницию.

Важнейшим средством противодействия коррупции является деятельность институтов гражданского общества, направленная на преодоление этого негативного явления. Думается, особое значение в данном случае имеет развитие институтов общественного контроля. Не случайно поэтому, что среди основных принципов противодействия коррупции в Кыргызской Республике называется, в частности, обеспечение правовой регламентации общественного контроля, взаимное сотрудничество Кыргызской Республики, т.е. государства с институтами гражданского общества (п. 6 и п. 11 ст. 3 Закона Кыргызской Республики от 8 августа 2012 года № 153 «0 противодействии коррупции»). В свою очередь Постановление Правительства Кыргызской Республики от 30 апреля 2913 года № 220 «0 мерах по реформированию органов внутренних дел Кыргызской Республики» [19]. специально предусматривает, что в ходе реализации мер по реформированию органов внутренних дел будут, в частности, обеспечен такой результат, как создание устойчивой системы гражданского контроля за деятельностью органов внутренних дел.

Также как в недавнем прошлом в России, органы внутренних дел Кыргызской Республики переживают стадию реформирования. Предпринимаемые меры направлены на достижение главной цели - создание эффективной системы обеспечения правопорядка и общественной безопасности, пользующейся доверием со стороны общества.

В этой связи интересной тенденцией следует признать попытку развития наряду с традиционной правоохранительной направленностью деятельности органов внутренних дел также сервисной (оказание услуг) функции. Предусматривается, что вся деятельность милиции должна быть ориентирована на обеспечение в полном объеме, в частности предоставления помощи и правоохранительных услуг населению.Таким образом, имеет место попытка осуществить переход полицейской (милицейской) деятельности на, так называемую социализированную модель. Принципиальное отличие этой модели от прежней, если так можно выразиться, модели традиционной состоит в переосмыслении роли и места полиции в обществе и государстве: 
1. Позиционирование полиции не как органа государственной власти, наделенного правом на применение законных мер принуждения, а как государственной службы, созданной для помощи и содействия гражданам. 2. Полиция - государственная служба, которая должна не только противодействовать преступности, но и выполнять более широкий круг функций: оказание миротворческих и гармонизирующих услуг местному сообществу и гражданам [20]. В результате суть полиции определяется посредством таких сущностных атрибутов, которые позволяют говорить о ней как об органе государственной власти, деятельность которого связана с помощью и оказанием разнообразных услуг гражданам, обществу и государству [21.1]. Подобный подход характерен для экономически развитых правовых демократических государств современного мира таких, например, как Великобритания и Германия. Последняя, кстати сказать, с полным основанием может быть названа родоначальником указанной трансформации полиции, которая стала возможна вследствие усилий немецкого народа и демократического германского государства по преодолению последствий тоталитарного режима периода Третьего Рейха.

Правда, несмотря на декларируемые установки на развитие сервисной функции в части 1 Закона Кыргызской республики от 11 января 1994 г. № 1360XII «Об органах внутренних дел Кыргызской Республики» органы внутренних дел Кыргызской Республики определяются в их традиционном понимании, а именно как государственный вооруженный правоохранительный орган, осуществляющий исполнительно-распорядительные функции по обеспечению общественного порядка, безопасности личности и общества и борьбе с преступностью.

Лицо, поступающее на службу в органы внутренних дел, должно быть достаточно профессионально подготовленным и соответствовать квалификационным требованиям. В их число входят требования к уровню профессионального образования, стажу службы в органах внутренних дел или стажу (опыту) работы по специальности, профессиональным знаниям и навыкам, состоянию здоровья сотрудников органов внутренних дел, необходимые для выполнения функциональных обязанностей по замещаемой должности.

Согласно п. 19 Положения на службу в органы внутренних дел принимаются в добровольном порядке граждане Кыргызской Республики, не имеющие гражданства другого государства, не имеющие судимость за уголовные преступления, независимо от того погашена или снята эта судимость, не моложе 19 лет (за исключением лиц, обучающихся в учебных заведениях МВД и равнозначных учебных заведениях других государств) годные к службе в органах внутренних дел, обладающие квалификационными знаниям, предъявляемым к сотрудникам органов внутренних дел, независимо от национальности, пола, социального происхождения, имущественного и должностного положения, отношения к религии, способные по своим личным, деловым и моральным качествам, отслужившие срочную военную службу, альтернативную (вневойсковую службу) по основаниям, вытекающим из семейного положения или имеющие звание офицера запаса.

Нельзя не отметить, что ранее действовавшее Положение о прохождении службы рядовым и начальствующим составом органов внутренних дел Кыргызской Республики (подпункт «б» пункта 30), утвержденное Указом Президента Кыргызской Республики от 30 октября 2009 г. УП № 480, допускало прием на службу гражданина, если он хотя в прошлом и осуждался, но судимость была снята или погашена в установленном порядке. Отказ от такого подходадел следует безусловно поддержать. Он в полной мере соответствует мировой практике, включая практику российскую. Действительно, на службе в органах внутренних дел, которая связана с применением мер государственного принуждения и совершением широкого спектра юридически значимых действий, а потому имеет огромный потенциал для злоупотреблений и всевозможных нарушений прав граждан, должны находиться только лица с безупречной репутацией, которым общество и выражающее его интересы государство доверяет, а потому наделяет значительными властными полномочия.

Среди оснований, исключающих принятие гражданина на службу в органы внутренних дел, хотелось бы также выделить увольнение из органов внутренних дел, а также из других министерств и ведомств по отрицательным мотивам, предусмотренным пунктами «т» (за грубое нарушение служебной дисциплины), «у» (за совершение проступков, несовместимых с требованиями, предъявляемыми к личным, нравственным качествам сотрудника, а также, если эти действия являются основанием для утраты к нему доверия), «ф» (в связи с осуждением за преступление, после вступления обвинительного приговора в законную силу), «х» (за предоставление подложных документов или заведомо ложных сведений при по- 
ступлении на службу в органы внутренних дел), «ц» (за привлечение к уголовной ответственности, но впоследствии органами следствия либо судом уголовные дела в отношении них были прекращены, кроме прекращенных по пунктам 1, 23 части 1 статьи 28 УПК Кыргызской Республики или оправданных судом по части 1 статьи 316 УПК Кыргызской Республики) пункта 106 Положения. Как видно, в данном случае имеется четкая правовая связь между службой в органах внутренних дел и государственной службой в других министерствах и ведомствах, которая регламентируется Законом Кыргызской Республики от 11 августа 2004 года № 114 «0 государственной службе». Кстати сказать, в данном нормативном правовом акте даже имеется специальная статья 16-1, предусматривающая наличие Реестра лиц, освобожденных с государственной службы по специальным основаниям, в котором содержатся их персональные данные. Нельзя не отметить, что кыргызстанское законодательство в данном случае оказывается более жестким по сравнению с аналогичным российским законодательством, которое не предусматривает запрет на прием на государственную службу будь то служба в органах внутренних дел или государственная гражданская служба на том основании, что лицо ранее привлекалось к дисциплинарной ответственности, даже в том случае, если речь идет, скажем, об увольнении в связи с утратой доверия (например, ст. 59-2 Федерального закона от 27 июля 2004 г. «0 государственной гражданской службе Российской Федерации»).

При приеме граждан на службу в органы внутренних дел, в целях уточнения сведений, касающихся самого кандидата, его родственников и близких связей, проводится специальная проверка. Осуществляются мероприятия по проверке по оперативно-справочным учетам кандидата и его близких родственников. Специальная проверка проводится путем использования оперативных возможностей органов внутренних дел и органов национальной безопасности Кыргызской Республики. После окончания специальной проверки работником кадрового аппарата составляется заключение о ее результатах. Материалы специальной проверки хранятся в личном деле. Порядок отбора граждан на службу в органы внутренних дел, а также порядок и сроки проведения специальной проверки определяются приказом министра внутренних дел.

Контракт о службе в органах внутренних дел. Согласно п. 35 Положения допускается замещение должностей рядового и начальствующего состава органов внутренних дел, в том числе профессорско-преподавательских должностей, на контрактной основе. Таким образом, контракт является той формой замещения должностей, которая по законодательству возможна, но не является общеобязательной, а применяется выборочно, когда это считается целесообразным, исходя из служебной необходимости и особенностей исполнения должностных полномочий. Следовательно, по действующему законодательству Кыргызской Республики основным способом замещения должностей в органах внутренних дел является безальтернативное назначение. В отличие от конкурса, при котором существует конкуренция, как минимум между двумя кандидатами на должность, назначение основано исключительно на усмотрении уполномоченного на то руководителя органов внутренних дел в соответствии с перечнем должностей МВД Кыргызстана, утвержденным министром. Конечно, расстановка кадров, обеспечение качественного комплектования должностей рядового и начальствующего состава органов внутренних дел согласно п. 38 Положения являются одними из основных обязанностей непосредственных руководителей и эту обязанность, очевидно, нужно должным образом исполнять, при решении кадровых вопросов нельзя исключать злоупотреблений, протекционизма, отступлений о принципа законности, когда во главу угла ставится не профессионализм кандидата на должность и его личностные качества (например, честность, принципиальность, бескомпромиссность в отстаивании требований закона, защите прав и свобод человека и гражданина), а преданность начальству, те же отношения родства или свойства, лесть, подхалимство и угодничество.

В соответствии с контрактом о службе в органах внутренних дел гражданин обязуется выполнять возложенные на него служебные обязанности, соблюдать Присягу, внутренний распорядок и требования Положения о прохождении службы рядовым и начальствующим составом органов внутренних дел Кыргызской Республики, а МВД обязуется обеспечивать ему предоставление всех видов довольствия, права, льготы и создавать условия для прохождения службы в органах внутренних дел, предусмотренные Законом Кыргызской Республики от 11 января 1994 г. № 1360-ХІІ«Об органах внутренних дел Кыргызской Республики», Положением и контрактом.

В контракте предусматриваются юридические последствия, которые наступают в связи с невыполнением сторонами взятых на себя обязательств. 
Контракт заключается в письменной форме, его условия не могут ухудшать служебное и социальное положение сотрудника, которое предусмотрено Законом Кыргызской Республики Республики от 11 января 1994 года № 1360-XII«Об органах внутренних дел Кыргызской Республики».

Срок, на который заключается контракт о службе в органах внутренних дел,составляет 3 года и может быть продлен или перезаключен по соглашению сторон не позднее, чем за 1 месяц до окончания срока, установленного в контракте. Непродление или неперезаключение контракта является основанием для увольнения из органов внутренних дел.

В случае служебной необходимости сотрудник может привлекаться для выполнения обязанностей, не предусмотренных контрактом, на срок до одного месяца в течение календарного года.

При приеме граждан на службу в органы внутренних дел Кыргызской Республики, а также при переводе сотрудников из числа рядового и младшего начальствующего состава на офицерскую должность, начальник соответствующего органа внутренних дел может назначить их на должность с испытательным сроком до 3-х месяцев с выплатой заработной платы по должности. Как видно требование об установлении испытательного сока не является императивным. Этот срок устанавливается по усмотрению начальника органа внутренних дел. Видимо, такой подход обусловлен стремлением повысить ответственность соответствующего руководителя, предоставить ему возможность лучше присмотреться к сотруднику, заранее выявить его сильнее и слабые стороны. Испытательный срок позволяет это сделать.

Сотрудник, впервые поступающий на службу в органы внутренних дел, принимает присягу, которая является его официальным и торжественным обещанием, клятвой на верность своему народу. Текст присяги содержится в п. 31 Положения. Принимающий присягу подписывает ее текст, который хранится в личном деле сотруднике. Порядок принятия присяги определяет министр внутренних дел. Присяга является подтверждением особых отношений преданности, служебного долга и верности, которые возникают между гражданином, поступившим на службу в органы внутренних дел, и государством.В этом отношении государственная служба в органах внутренних дел близка к военной службе, на которой закон также предусматривает принятие присяги. Напротив, для обычных государственных служащих (государственной гражданской службы в Кыргызской Республике закон не выделяет - Авт.), чей статус определяется Законом Кыргызской Республики от 11 августа 2004 года № 114 «0 государственной службе», принятие присяги не предусмотрено.

Специальные звания. Как всякая военизированная организация, органы внутренних дел Кыргызской Республики имеют четко выстроенную иерархию должностей, место в которой определяется наряду с должностью еще и специальным званием. В Кыргызской Республике сотрудникам органов внутренних дел присваиваются либо специальные звания милиции,либо внутренней службы. Эти звания присваиваются им персонально с учетом их квалификации, образования, образования, отношения к службе, выслуги лет, занимаемой должности, сдачи нормативов ССК (служебноспортивного комплекса), а также иных условий, предусмотренных Положением.

Предусмотрены следующие специальные звания:

- для рядового состава - рядовой милиции, рядовой внутренней службы;

- для младшего начальствующего состава -младший сержант милиции, младший сержант внутренней службы, сержант милиции, сержант внутренней службы, старший сержант милиции, старший сержант внутренней службы, старшина милиции, старший сержант внутренней службы, прапорщик милиции, прапорщик внутренней службы, старший прапорщик милиции, старший прапорщик внутренней службы;

- для среднего начальствующего состава младший лейтенант милиции, младший лейтенант внутренней службы, лейтенант милиции, лейтенант внутренней службы; старший лейтенант милиции, старший лейтенант внутренней службы, капитан милиции, капитан внутренней службы;

- для старшего начальствующего состава - майор милиции, майор внутренней службы, подполковник милиции, подполковник внутренней службы, полковник милиции, полковник внутренней службы;

- для высшего начальствующего состава - генерал-майор милиции, генерал-майор внутренней службы, генерал-лейтенант милиции, генерал-лейтенант внутренней службы, генерал-полковник милиции, генерал-полковник внутренней службы.

Как видно, в органах внутренних дел Кыргызской Республики установлены специальные 
звания, аналогичные тем, что предусмотрены российским законодательством для сотрудников полиции и органов внутренних дел в целом.

В зависимости от последовательности присвоения специальные звания подразделяются на первые и очередные. Первые специальные звания рядового и младшего начальствующего состава присваиваются гражданам при приеме на службу в органы внутренних дел одновременно с назначением на должность. Специальные звания до полковника милиции, «полковника внутренней службы» включительно присваиваются в порядке, определяемом министром внутренних дел. Специальные звания высшего начальствующего состава присваиваются Президентом Кыргызской Республики.

Очередные специальные звания сотрудникам начальствующего состава присваиваются в последовательном порядке при положительной служебной характеристике, успешной сдаче нормативов ССК (служебно-спортивного комплекса), соответствии очередного звания званию, предусмотренному по занимаемой штатной должности, и по истечении установленного срока выслуги в предыдущем специальном звании (п. 63 Положения).

Касаясь процедуры его присвоения, следует сказать, что очередное специальное звание, соответствующее занимаемой должности, присваивается сотруднику на основании представления непосредственного начальника в день истечения срока его службы в предыдущем звании, если отсрочка не вызвана техническими причинами (отсутствие должностных лиц в выходной день, непредставление в кадровую службу или представление с опозданием справки о сдаче норм СКК (служебно-спортивного комплекса). Таким образом, представление является тем юридическим фактом, наличие которого признается законодательством обязательным.

Именно поэтому, установлена юридическая ответственность за задержку представления сотрудника к специальному званию.Должностные лица органов внутренних дел, необоснованно задержавшие представление сотрудника о присвоении очередного и первого специального звания, привлекаются к дисциплинарной ответственности (п. 65 Положения).

В п. 75 Положения нормативно закреплены основания, при наличии которых представление к присвоению очередных специальных званий не производится. Они не присваиваются сотрудникам: находящимся в распоряжении соответствующего органа внутренних дел; имеющим дисциплинарные взыскания; в отношении которых возбуждены уголовные дела; проводится проверка по фактам нарушения служебной дисциплины; не сдавшим нормативы служебно-спортивного комплекса (СКС). Представление соответствующих сотрудников к присвоению званий производится после прекращения перечисленных оснований. При этом сами по себе данные основания представляются достаточно спорными и неоднозначными. Как, например, быть с презумпцией невиновности? Факт возбуждения в отношении сотрудника уголовного дела или проведение проверки по фактам нарушения служебной дисциплины еще не предрешает вопрос о его виновности, которую может установить только суд.Поэтому, не представлять такого сотрудника к очередному специальному званию вряд ли правильно. Думается, действующие нормы п. 75 Положения должны быть скорректированы. Приходится признать, что в России также существует, в общем, схожая ситуация. Федеральный закон от30 ноября 2011 г. «0 службе в органах внутренних дел Российской Федерации и внесении изменений в отдельные законодательные акты Российской Федерации» также предусматривает перечень оснований, при наличии которых присвоение сотруднику органов внутренних дел приостанавливается. Правда, в российском законеиспользуется несколько более мягкая формулировка«приостанавливается», тогда как кыргызстанский нормативный правовой акт оперирует жестким термином «не производится». Таким образом, в России присвоении специального звания представляет собой, по сути, своеобразную административную процедуру, которая делится на стадии, в том числе такую факультативную стадию, как приостановление производства по делу. Конечно, и российская формулировка также мало согласуется с презумпцией невиновности. Но это в целом характерно для службы в правоохранительных органах, включая полицию и органы внутренних дел. Так, типичным подходом является увольнение сотрудника, нередко даже, что называется «задним числом», совершившего преступление или другое правонарушение, бросающее, по мнению руководителей, тень на репутацию тех же, к примеру, органов внутренних дел. При этом, обвинительного приговора суда, вступившего в законную силу и установившего тем самым вину того или иного лица из числа сотрудников, никто не ожидает. Обычно немедленно увольняются те, сотрудники, кто попал в поле зрения прессы и их дело получило значительный общественный резонанс. Как представляется, руководство органов внутренних дел тем самым 
дистанцируется от такого сотрудника, снимая с себя и перекладывая исключительно на конкретного человека ответственность за, возможно, и не совершенное им преступление. Думается, было бы правильным установить де-юре запрет увольнять сотрудника до вынесения обвинительного приговора суда и вступления его в силу. Его служба в этом случае могла бы только на время приостанавливаться. В этом случае появлялась бы возможность определить и меру ответственности тех руководителей органов внутренних дел, из-за недостаточного контроля которых за подчиненными последние совершили преступления и другие злоупотребления. Это особенно важно, если речь идет о должностных преступлениях коррупционной направленности.

Высшее специальное звание - «генерал-майор милиции (внутренней службы») присваивается лицу, замещающему должность министра внутренних дел, не ранее 6 месяцев, а лицам, непрерывно занимающим другие должности, которые предусматривают замещение лицами с высшим специальным званием, - не ранее 2 лет со дня их назначения. Как видно, предполагается, что министр внутренних дел также является сотрудником, тесно связан с той системой, которую возглавляет. Возможно, в нынешних условия, когда в органах внутренних дел Кыргызской Республики накопилось много серьезных проблем и они находятся в стадии реформирования и, принимая во внимание то обстоятельство, что, как отмечалось выше, предпринимаются попытки развивать сервисную функцию органов внутренних дел, стоит подумать о назначении на должность министра гражданского лица, не связанного с системой органов внутренних дел, но при этом достаточно известного в стране, имеющего авторитет в обществе и пользующегося уважением у сограждан. Думается, тогда и реформы пойдут быстрее и эффект от них окажется выше. Опыт нашей страны, когда Указом Президента Российской Федерации от 28 марта 2001 г. № 358 «0 Министре внутренних дел Российской Федерации», на должность главы МВД был назначен Б.В.Грызлов - человек сугубо гражданский, убедительно подтверждает правильность предлагаемого подхода. Именно в бытность министром Б.В.Грызлова начались качественные системные преобразования органов внутренних дел, которые, как известно, в начале 2000-х годов пребывали в состоянии глубокого кризиса.

В ст. 10 Закона устанавливается, что специальное звание сотрудника органов внутренних дел приравнивается к воинскому званию. Напро- тив, в России именно воинские звания обладают некоторым так сказать «старшинством». Так, в ч. 6 ст. 41 Федерального закона от 30 ноября 2011 г. «0 службе в органах внутренних дел Российской Федерации и внесении изменений в отдельные законодательные акты Российской Федерации» гражданину, впервые поступившему на службу в органы внутренних, дел первое специальное звание присваивается в соответствии с замещаемой должностью, но не выше подполковника полиции, подполковника внутренней службы, подполковника юстиции, если он не имеет более высокого воинского звания или специального звания. Следовательно, если его воинское звание выше, скажем, полковник, то ему также должно присваиватьсоответствующее первое специальное звание, например, полковник полиции. Тем самым обеспечивается исторически существующий еще со времен петровской Табели о рангах 1722 г. приоритет военной службы над другими видами государственной службы.

Важнымаспектом службы в органах внутренних дел является регламентация дисциплинарной ответственности и поощрений сотрудников. Перечень дисциплинарных взысканий и мер поощрения дан в Положении. Процедура их применения должна быть урегулирована в специальном нормативном правовом акте - Дисциплинарном уставе органов внутренних дел Кыргызской Республики. В ходе реформы органов внутренних дел под эгидой Управления Организации Объединенных Нацийпо наркотикам и преступности (УНП ООН) был разработансоответствующий проект и проведенаего правовая, правозащитная и антикоррупционная экспертиза. Анализ основных положений проекта был дан автором в специальном исследовании [23]. Поэтому в настоящей статье дисциплинарная ответственность и меры поощрения не рассматривались.

В заключении хотелось бы отметить, что в ходе официального визита в Российскую Федерацию Президента Кыргызской Республики Алмазбека Атамбаева, который состоялся в августе 2014 г., было достигнуто соглашение о присоединении Кыргызстана к Таможенному и Евразийскому экономическому союзу до конца 2014 г. Учитывая данное обстоятельство, можно с большой долей вероятности прогнозировать, что развитие законодательства о службе в органах внутренних дел Кыргызской Республики будет во многом ориентироваться на соответствующее российское законодательство. Уже сейчас между ними существует очевидное сходство. Поэтому взаим- 
ное изучение опыта государственной службы в органах внутренних обеих стран представляется актуальным и практически полезным, тем более, что в нашей стране в основном уже завершились, причем достаточно успешно, мероприятия по реформированию органов внутренних дел. В пользу этого свидетельствует, в частности, заметно возросшее доверие российских граждан к полиции. Так, по данным социологического опроса, проведенного Всероссийским центром изучения общественного мнения 1-2 ноября 2014 г., с доверием к полиции относятся 56\% россиян [24]. В свою очередь, ссылаясь на данные Ассоциации адвокатов России за права человека, Руководитель Администрации Президента Российской Федерации С.Б.Иванов отметил, что на $60 \%$ сократились и случаи вымогательства мелких взяток в органах внутренних дел [25]. Думается, российский опыт мог бы быть с успехом передан и нашим кыргызстанским партнерам, для которых проблема реформирования органов внутренних дел продолжает стоять крайне остро.

\section{Библиография:}

1. Гришковец А.А. Законодательное регулирование государственной службы в странах Балтии // Журнал российского права. 2000. № 4. С. 107.

2. Джамшедов Д.Н. Государственная служба Республики Таджикистан (конституционно-правовой аспект). Автореф. дисс. на соиск уч. ст. канд.юрид. наук. М., Институт государства и права РАН. 2011; Мамырбаева 3.А. Административно-правовое регулирование государственной службы в органах внутренних дел Кыргызской Республики. Автореф. дисс. на соиск уч. ст. канд.юрид. наук. М., Академия управления МВД России. 2010; Турисбек А.3. Государсвтенная служба Республики Казахстан (проблемы теории и практики) Автореф. дисс. на соиск. уч. ст. докт. юрид. наук. М., Институт государства и права РАН. 2012; Шерипов Н.Т. Государственная гражданская служба Кыргызской Республики (административно-правовое исследование). Автореф. дисс. на соиск. уч. ст. докт. юрид. наук. Тюмень. Тюменский государственный университет. 2011. См.: «Слово Кыргызстана». 2013. 23 января.

3. Бородин Е.А. Внутриполитическое и социально-экономическое развитие Кыргызстана. М., Восток-Запад. 2011. С. 66.

4. Конституция Кыргызской Республики. Конституции стран Азии в трех томах. Том 2 Средняя Азия и Индостан/ Под ред. Т.Я.Хабриевой. Институт законодательства и сравнительного правоведения при Правительстве Российской Федерации. М., Норма. 2010. С. 454-492.

5. Ведомости ЖогоркуКенешаКыргызской Республики. 1996. № 3. Ст. 77.

6. Нормативные акты Правительства Кыргызской Республики (приложение к газете «ЭркинТоо») от 28 июня 2013 года № 11-12.

7. Указ Президента Кыргызской Республики от 30 октября 2009 года УП № 480 «Об утверждении Положения о прохождении службы рядовым и начальствующим составом органов внутренних дел Кыргызской Республики»// ЭркинТоо. 2009. 6 ноября.

8. Ведомости Жогорку Кенеша Кыргызской Республики. № 12. 2004. Ст. 529.

9. Мамырбаева З.А. Административно-правовое регулирование государственной службы в органах внутренних дел Кыргызской Республики. Автореф. дис. ... канд. юрид. наук. - М., 2010. С. 23.

10. Бородин Е.А. Внутриполитическое и социально-экономическое развитие Кыргызстана. М., Восток-Запад. 2011. С. 130.

11. Ситнянский Г. Отношения севера и юга Киргизии: история и современность. М., Институт этнологии и антропологии РАН/ Документ № 198.

12. Хотя термин «трайболизм» и имеет латинское происхождение (от лат. triba -племя), но вошел он в широкий оборот из английского языка (от англ.tribe-племя)-и представляет собой форму общественно-политической племенной обособленности, выражающейся в формировании органов государственной власти на основеродоплеменных связей.

13. Шерипов Н.Т. Государственная гражданская служба Кыргызской Республики (административно-правовое исследование): Автореф. д-ра. юрид. наук. - Тюмень. 2011. С. 3.

14. Разуваева Н.И. Подбор и аттестации кадров органов внутренних дел (административно-правовые и организационные аспекты): Дис. ... канд. юрид. наук. - Воронеж, 2014. - С. 104.

15. Расширенное заседание коллегии МВД 8 февраля 2013 года//URL: http://президент.pф /news/17461 (дата обращения: 30.11.2014).

16. Центр гуманитарных технологий (http://gtmarket.ru/news2014/12/03/7004). Дата обращения 04.12.2014. 17 Бельский К.С. Об уточнении понятия «коррупция»// Государство и право. 2012. № 13. С. 27. 18. ЭркинТоо. 2012. 14 августа. 19 ЭркинТоо. 2013. 9 мая. 20. Рюден Е.Ю., Астапенко П.Н., Дербичева С.А. Административная модернизация полицейской службы: стратегия и методология (практика Федеративной Республики Германии и Российской Федерации в сравнительном анализе). - М., 2011. - С. 10. 21 Рюден Е.Ю., Астапенко П.Н., Дербичева С.А. 
Административная модернизация полицейской службы: стратегия и методология (практика Федеративной Республики Германии и Российской Федерации в сравнительном анализе). - М., 2011. - С. 10. 22. Собрание законодательства РФ. - 2011. - № 49 ч. 1. - Ст. 7020. 23 Гришковец А.А. Проект Дисциплинарного устава органов внутренних дел Кыргызской Республики: достоинства и недостатки // Полицейская деятельность. - 2014. - №5 (21). - C. 452. 24. http://wciom.ru/index.php?id=459\&uid=115045 (дата обращения 10.12.2014) 25. http:// kommersant.ru/doc/2629010 (дата обращения 09.12.2014)

17. М.В. Костенников, А.В. Куракин, И.Н. Кошелев Административно-правовое регулирование обеспечения собственной безопасности и противодействия коррупции в органах внутренних дел (ч. 2). // Административное и муниципальное право. - 2011. - 2. - С. 38 - 45.

18. Костенников М.В., Куракин А.В. Административно-правовое противодействие коррупции в системе государственной службы и в деятельности сотрудников полиции Российской Федерации и зарубежных государств. // Полицейская деятельность. - 2011. - 1. - С. 10 - 16.

19. Костенников М.В., Куракин А.В., Кошелев И.Н. Административно-правовое регулирование обеспечения собственной безопасности и противодействия коррупции в органах внутренних дел (ч. 3 окончание начало в № 1 , 2 - 2011 г.) // Административное и муниципальное право. - 2011. - 4. - С. 52 - 61.

20. Куракин А.В., Костенников М.В. Административно-правовое противодействие коррупции в системе государственной службы и в деятельности сотрудников полиции Российской Федерации и зарубежных государств // Полицейская и следственная деятельность. - 2013. - 1. - C. 65 - 83. DOI: 10.7256/2409-7810.2013.1.735. URL: http://www.e-notabene.ru/pm/article_735.html

21. Куракин А.В. Административно-правовые аспекты юридической ответственности в механизме противодействия коррупции в системе государственной службы Российской Федерации // NB: Административное право и практика администрирования. - 2013. - 7. - C. 137 - 157. DOI: 10.7256/2306-9945.2013.7.9954. URL: http://www.enotabene.ru/al/article_9954.html

22. Куракин А.В., Кулешов Г.Н. Государственная служба и информационные технологии // NB: Административное право и практика администрирования. - 2013. - 12. - С. 1 - 20. DOI: 10.7256/2306-9945.2013.12.10701. URL: http:// www.e-notabene.ru/al/article_10701.html

23. Куракин А.В. Международное и административное право и противодействие коррупции в системе государственной гражданской службы // NB: Административное право и практика администрирования. - 2014. - 1. - C. 53 - 81. DOI: 10.7256/2306-9945.2014.1.11051. URL: http://www.e-notabene.ru/al/article_11051.html

24. М.В. Костенников, А.В. Куракин, И.Н. Кошелев Административно-правовое регулирование обеспечения собственной безопасности и противодействия коррупции в органах внутренних дел (ч. 1). // Административное и муниципальное право. - 2011. - 1. - С. 40 - 47.

\section{References (transliterated):}

1. Grishkovets A.A. Zakonodatel'noe regulirovanie gosudarstvennoi sluzhby v stranakh Baltii // Zhurnal rossiiskogo prava. 2000. № 4. S. 107.

2. Dzhamshedov D.N. Gosudarstvennaya sluzhba Respubliki Tadzhikistan (konstitutsionno-pravovoi aspekt). Avtoref. diss. na soisk uch. st. kand.yurid. nauk. M., Institut gosudarstva i prava RAN. 2011; Mamyrbaeva Z.A. Administrativno-pravovoe regulirovanie gosudarstvennoi sluzhby v organakh vnutrennikh del Kyrgyzskoi Respubliki. Avtoref. diss. na soisk uch. st. kand.yurid. nauk. M., Akademiya upravleniya MVD Rossii. 2010; Turisbek A.Z. Gosudarsvtennaya sluzhba Respubliki Kazakhstan (problemy teorii i praktiki) Avtoref. diss. na soisk. uch. st. dokt. yurid. nauk. M., Institut gosudarstva i prava RAN. 2012; Sheripov N.T. Gosudarstvennaya grazhdanskaya sluzhba Kyrgyzskoi Respubliki (administrativno-pravovoe issledovanie). Avtoref. diss. na soisk. uch. st. dokt. yurid. nauk. Tyumen'. Tyumenskii gosudarstvennyi universitet. 2011. Sm.: «Slovo Kyrgyzstana». 2013. 23 yanvarya.

3. Borodin E.A. Vnutripoliticheskoe i sotsial'no-ekonomicheskoe razvitie Kyrgyzstana. M., Vostok-Zapad. 2011. S. 66.

4. Konstitutsiya Kyrgyzskoi Respubliki. Konstitutsii stran Azii v trekh tomakh. Tom 2 Srednyaya Aziya i Indostan/ Pod red. T.Ya.Khabrievoi. Institut zakonodatel'stva i sravnitel'nogo pravovedeniya pri Pravitel'stve Rossiiskoi Federatsii. M., Norma. 2010. S. 454-492.

5. Vedomosti ZhogorkuKeneshaKyrgyzskoi Respubliki. 1996. № 3. St. 77.

6. Normativnye akty Pravitel'stva Kyrgyzskoi Respubliki (prilozhenie k gazete «ErkinToo») ot 28 iyunya 2013 goda № 11-12.

7. Ukaz Prezidenta Kyrgyzskoi Respubliki ot 30 oktyabrya 2009 goda UP № 480 «Ob utverzhdenii Polozheniya o prokhozhdenii sluzhby ryadovym i nachal'stvuyushchim sostavom organov vnutrennikh del Kyrgyzskoi Respubliki»// ErkinToo. 2009. 6 noyabrya.

8. Vedomosti Zhogorku Kenesha Kyrgyzskoi Respubliki. № 12. 2004. St. 529.

9. Mamyrbaeva Z.A. Administrativno-pravovoe regulirovanie gosudarstvennoi sluzhby $\mathrm{v}$ organakh vnutrennikh del Kyrgyzskoi Respubliki. Avtoref. dis. ... kand. yurid. nauk. - M., 2010. S. 23.

10. Borodin E.A. Vnutripoliticheskoe i sotsial'no-ekonomicheskoe razvitie Kyrgyzstana. M., Vostok-Zapad. 2011. S. 130.

11. Sitnyanskii G. Otnosheniya severa i yuga Kirgizii: istoriya i sovremennost'. M., Institut etnologii i antropologii RAN/ Dokument № 198. 
Административное и муниципальное право 1 (85) • 2015

12. Khotya termin «traibolizm» i imeet latinskoe proiskhozhdenie (ot lat. triba -plemya), no voshel on v shirokii oborot iz angliiskogo yazyka (ot angl.tribe-plemya)-i predstavlyaet soboi formu obshchestvenno-politicheskoi plemennoi obosoblennosti, vyrazhayushcheisya v formirovanii organov gosudarstvennoi vlasti na osnoverodo-plemennykh svyazei.

13. Sheripov N.T. Gosudarstvennaya grazhdanskaya sluzhba Kyrgyzskoi Respubliki (administrativno-pravovoe issledovanie): Avtoref. d-ra. yurid. nauk. - Tyumen'. 2011. S. 3.

14. Razuvaeva N.I. Podbor i attestatsii kadrov organov vnutrennikh del (administrativno-pravovye i organizatsionnye aspekty): Dis. ... kand. yurid. nauk. - Voronezh, 2014. - S. 104.

15. Rasshirennoe zasedanie kollegii MVD 8 fevralya 2013 goda//URL: http://prezident.rf /news/17461 (data obrashcheniya: 30.11.2014).

16. Tsentr gumanitarnykh tekhnologii (http://gtmarket.ru/news2014/12/03/7004). Data obrashcheniya 04.12.2014. 17 Bel'skii K.S. Ob utochnenii ponyatiya «korruptsiya»// Gosudarstvo i pravo. 2012. № 13. S. 27. 18. ErkinToo. 2012.14 avgusta. 19 ErkinToo. 2013. 9 maya. 20. Ryuden E.Yu., Astapenko P.N., Derbicheva S.A. Administrativnaya modernizatsiya politseiskoi sluzhby: strategiya i metodologiya (praktika Federativnoi Respubliki Germanii i Rossiiskoi Federatsii v sravnitel'nom analize). - M., 2011. - S. 10. 21 Ryuden E.Yu., Astapenko P.N., Derbicheva S.A. Administrativnaya modernizatsiya politseiskoi sluzhby: strategiya i metodologiya (praktika Federativnoi Respubliki Germanii i Rossiiskoi Federatsii v sravnitel'nom analize). - M., 2011. - S. 10. 22. Sobranie zakonodatel'stva RF. - 2011. - № 49 ch. 1. - St. 7020.23 Grishkovets A.A. Proekt Distsiplinarnogo ustava organov vnutrennikh del Kyrgyzskoi Respubliki: dostoinstva i nedostatki // Politseiskaya deyatel'nost'. - 2014. - №5 (21). - S. 452. 24. http://wciom.ru/index.php?id=459\&uid=115045 (data obrashcheniya 10.12.2014) 25. http://kommersant.ru/doc/2629010 (data obrashcheniya 09.12.2014)

17. M.V. Kostennikov, A.V. Kurakin, I.N. Koshelev Administrativno-pravovoe regulirovanie obespecheniya sobstvennoi bezopasnosti i protivodeistviya korruptsii v organakh vnutrennikh del (ch. 2). // Administrativnoe i munitsipal'noe pravo. - 2011. - 2. - C. $38-45$.

18. Kostennikov M.V., Kurakin A.V. Administrativno-pravovoe protivodeistvie korruptsii v sisteme gosudarstvennoi sluzhby i v deyatel'nosti sotrudnikov politsii Rossiiskoi Federatsii i zarubezhnykh gosudarstv. // Politseiskaya deyatel'nost'. 2011. - 1. - C. $10-16$.

19. Kostennikov M.V., Kurakin A.V., Koshelev I.N. Administrativno-pravovoe regulirovanie obespecheniya sobstvennoi bezopasnosti i protivodeistviya korruptsii v organakh vnutrennikh del (ch. 3 okonchanie nachalo v № 1 , 2 - 2011 g.) // Administrativnoe i munitsipal'noe pravo. - 2011. - 4. - C. 52 - 61.

20. Kurakin A.V., Kostennikov M.V. Administrativno-pravovoe protivodeistvie korruptsii v sisteme gosudarstvennoi sluzhby i v deyatel'nosti sotrudnikov politsii Rossiiskoi Federatsii i zarubezhnykh gosudarstv // Politseiskaya i sledstvennaya deyatel'nost'. - 2013. - 1. - C. 65 - 83. DOI: 10.7256/2409-7810.2013.1.735. URL: http://www.e-notabene.ru/pm/ article_735.html

21. Kurakin A.V. Administrativno-pravovye aspekty yuridicheskoi otvetstvennosti v mekhanizme protivodeistviya korruptsii v sisteme gosudarstvennoi sluzhby Rossiiskoi Federatsii // NB: Administrativnoe pravo i praktika administrirovaniya. 2013. - 7. - C. 137 - 157. DOI: 10.7256/2306-9945.2013.7.9954. URL: http://www.e-notabene.ru/al/article_9954.html

22. Kurakin A.V., Kuleshov G.N. Gosudarstvennaya sluzhba i informatsionnye tekhnologii // NB: Administrativnoe pravo i praktika administrirovaniya. - 2013. - 12. - C. 1 - 20. DOI: 10.7256/2306-9945.2013.12.10701. URL: http://www.enotabene.ru/al/article_10701.html

23. Kurakin A.V. Mezhdunapodnoe i administrativnoe pravo i protivodeistvie korruptsii v sisteme gocudapctvennoi grazhdanskoi sluzhby // NB: Administrativnoe pravo i praktika administrirovaniya. - 2014. - 1. - C. 53 - 81 . DOI: 10.7256/2306-9945.2014.1.11051. URL: http://www.e-notabene.ru/al/article_11051.html

24. M.V. Kostennikov, A.V. Kurakin, I.N. Koshelev Administrativno-pravovoe regulirovanie obespecheniya sobstvennoi bezopasnosti i protivodeistviya korruptsii v organakh vnutrennikh del (ch. 1). // Administrativnoe i munitsipal'noe pravo. - 2011. - 1. - C. $40-47$. 